\title{
Response of suckler cows to the available sward height in different pastures
}

\author{
K Osoro, M Oliván, R Celaya, JJ Ormazábal \\ Instituto de Experimentación y Promoción Agraria, Apdo 13, 33300 Villaviciosa, Asturias, Spain
}

One hundred forty winter calving suckler cows and their calves were managed through several years (1990-94) during the spring (March-June) and summer (June-September) grazing seasons on pastures dominated by perennial ryegrass and white clover or in hill pastures of Agrostis curtisii-Festuca rubra with areas of Nardus stricta and Calluna vulgaris to study the animal response to the available sward height in both type of vegetations.

Sward height was measured weekly (HFRO, 1986. Hill Farming Research Organisation, Biennial Report, 1984-1985, 50-51) and cows and calves weighed two consecutive days at the beginning and at the end of each grazing season. Sward height ranged from 4.5 to $10.1 \mathrm{~cm}$ in ryegrass-white clover pastures and from 2.2 to 5.6 on hill vegetation community.

On perennial ryegrass-white clover pastures suckler cows were able to replenish $0.8 \mathrm{~kg}$ LW/day when sward height was around $8.0 \mathrm{~cm}$, maintaining weight in pastures with $6.0-6.5 \mathrm{~cm}$ sward height and losing around 0.5 $0.6 \mathrm{~kg} /$ day when the sward decreased to 4.5 $5.0 \mathrm{~cm}$ (Equation 1).

Calves live weight gains ranged from 0.88 to $0.98 \mathrm{~kg} /$ day in those managements where sward height ranged from 6.3 to $10.1 \mathrm{~cm}$. However in those where animals had only available $4.5-4.7 \mathrm{~cm}$ of sward height, calves gained only $0.61 \mathrm{~kg} /$ day (Equation 2).

In hill pastures the response found was different from that observed on ryegrass-white clover pastures. In vegetations where AgrostisFestuca height was $4.0-4.2 \mathrm{~cm}$, suckler cows maintained weight, and they were able to gain $0.3-0.5 \mathrm{~kg} / \mathrm{day}$ when the height of those grass species was $4.5-4.8 \mathrm{~cm}$. Live weight gains did not increase further when grazed sward was higher than $5 \mathrm{~cm}$. Very low sward heights are frequent during the summer grazing and suckler cows lose around $0.75 \mathrm{~kg} /$ day in sward with only $3.0 \mathrm{~cm}$ high (Equation 3 ).

Calves live weight gains were between 0.82$0.96 \mathrm{~kg} /$ day when Agrostis-Festuca height was $4.2-4.6 \mathrm{~cm}$, decreasing to $0.6 \mathrm{~kg} /$ day when sward height was reduced to $3.0 \mathrm{~cm}$ (Equation 4). These live weight gains are similar to those observed in calves grazing perennial ryegrass-white clover pastures with 6 to $10 \mathrm{~cm}$ and $4.5-5 \mathrm{~cm}$ height respectively.

Therefore the sward height in which suckler cows maximize performance is much lower in Agrostis-Festuca hill pastures $(4.5-5.0 \mathrm{~cm}$ ) than in perennial ryegrass $(8.0-10 \mathrm{~cm})$. Also the variation in live weight according to the changes in the available vegetation ( $\mathrm{cm}$ of sward height) are significantly different between both types of vegetation.

\begin{tabular}{llll}
\hline & Vegetation : perennial ryegrass-white clover & $\mathrm{n}$ & $\mathrm{R}^{2}$ \\
\hline Equation 1 & Cow $(\mathrm{kg} /$ day $)=-2.718( \pm 0.395)+0.440( \pm 0.062) \mathrm{X}_{1}$ & 10 & 0.85 \\
Equation 2 & Calf $(\mathrm{kg} /$ day $)=0.171( \pm 0.144)+0.110( \pm 0.022) \mathrm{X}_{1}$ & 10 & 0.72 \\
& Vegetation : Agrostis-Festuca hill pastures & & \\
\hline Equation 3 & Cow $(\mathrm{kg} /$ day $)=-2.681( \pm 0.402)+0.664( \pm 0.111) \mathrm{X}_{2}$ & 11 & 0.78 \\
Equation 4 & Calf $(\mathrm{kg} /$ day $)=0.079( \pm 0.074)+0.187( \pm 0.021) \mathrm{X}_{2}$ & 11 & 0.89 \\
\hline
\end{tabular}

$X_{1}=$ sward height in $\mathrm{cm}$, used range from 4.5 to $8.0 \mathrm{~cm} ; X_{2}=$ sward height in $\mathrm{cm}$, used range from 2.0 to $5.0 \mathrm{~cm} ; \mathrm{n}$ : number of treatments. 